\title{
Şârihlerinin İbn Mâlik'e yönelik bazı eleştirileri
}

\section{Hasan UÇAR 1}

\begin{abstract}
APA: Uçar, H. (2019). Şârihlerinin İbn Mâlik'e yönelik bazı eleştirileri. RumeliDE Dil ve Edebiyat Araşttrmaları Dergisi, (15), 505-521. DOI: 10.29000/rumelide.580732
\end{abstract}

\section{$\ddot{O} \mathbf{z}$}

İbn Mâlik, Arap dili gramerinin Sîbeveyhî’den sonraki en büyük isimlerindendir. Teshîlu'l-Fevâid ve Tekmîlu'l-Mekâsıd adlı eseri bu alanın en temel kaynaklarındandır. Eserini kendisi de şerh etmiş ve Elfiyye'sinde manzum olarak özetlemiştir. el-Murâdî, Ebû Hayyân, İbn Akîl, Hâlid el-Ezherî ve İbn Hişâm gibi pek çok müellif de İbn Mâlik’in bu eserini şerh etmişlerdir. Şârihlerin eser sahibine karşı mütevazı tutumu geleneğin bir özelliğidir. Ancak bu onların hataları görmezden gelmelerine veya eser sahibini eleştirmekten geri durmalarına sebep olmamıştır. Nitekim İbn Mâlik’in kendinden önceki dil bilimcilere eleştirileri olduğu gibi, kendisine de eleştiriler olmuştur. Sadece İbn Mâlik ile sınırlı olmayan bu durumun dil bilimcilerin birbirlerine veya bir dil bilimcinin diğerlerine itirazları üzerine yapılan müstakil çalışmalarda görmek mümkündür. Görüş farklılıklarının sebep olduğu nahiv uygulamaları ve dil bilimcilerin ekollerinin farklı olmasıyla açılanabilecek konuların izahı bu çalışmanın hedefi değildir. Zira böyle bir durumda eleştiren ve eleştirilen tarafların her birini destekleyen dil bilimciler olacak ve tartışmalar çalışmanın sınırlarını zorlayacaktır. Bu çalışmada, İbn Mâlik'e yönelik eleştiriler metot, içerik, dil ve üslup şeklinde üç başlık olarak incelenmiş ve her biri kendi içerisinde kategorize edilerek örnekler verilmiştir.

Anahtar kelimeler: İbn Mâlik, Elfiyye, teshîl, eleştiri, şârih.

\section{Some criticism from the reviewer on Ibn Malik}

\begin{abstract}
Ibn Malik is one of the biggest names in Arabic language after Sibeveyh. Teshîlu'l-Fevâid ve Tekmîlu'l-Mekâsıd among the most important sources of this field. He explained his work and summarized as a poem in his Elfiyye. Many writers such as al-Muradi, Abu Hayyan, Ibn Akil, Halid el-Azhari and Ibn Hisham have also commented on this work of Ibn Malik. The modest attitude of the reviewers against the author is a characteristic of tradition. But, this, didn't cause them to ignore the mistakes or stop them from criticizing the author. As a matter of fact, as Ibn Malik criticized the linguists before him, Ibn Malik had been criticized. It is possible to see this situation, which is not limited to Ibn Malik, in independent studies on linguists' objections to each other or to a linguist. Grammar practices caused by differences of opinion and the explication of the issues that can be explained by the differentiation of linguists' schools, are not the targets of this study. Because, in such a case, there will be linguists who support one of both sides and the discussions will push the limits of the study. In this study, criticisms of Ibn Malik were examined as three topics: method, content, language and style, and each of them is categorized and examples are given.
\end{abstract}

Keywords: Ibn Malik, Elfiyye, teshil, criticism, reviewer.

1 Dr. Öğr. Üyesi, Aksaray Üniversitesi, İslami İlimler Fakültesi, Temel İslam Bilimleri, Arap Dili ve Belagati (Aksaray, Türkiye), ucarhasan42@hotmail.com, ORCID ID: 0000-0003-1995-8414 [Makale kayt tarihi: 17.04.2019-kabul tarihi: 15.06.2019; DOI: 10.2900o/rumelide.580732] 


\section{Giriş}

Dil bilgisinin nazım olarak anlatımı olan İbn Mâlik'in Elfiyye'si, benzeri dünya tarihinde başka bir dilde görülmeyen bir şaheserdir. Esere yüzden fazla şerh ve haşiye yazılmıştır. Sahip olduğu değer, üzerinde daha çok çalışılmasına ve hatalarının tespit edilmesine vesile olmuştur.

Arap dilinde eleştiri kültürünün temeli olan itirâzât türü eserler çoktur. İbn Mâlik’in söz konusu eseriyle sınırlı olmayan bu gerçeği, dil bilimcilerin birbirlerine itirazları üzerine yapılan müstakil çalışmalarda görmek mümkündür.

Elfiyye'nin sahip olduğu prestij, onu eleştirilerden kurtarmaya yetmemiştir. Şârihlerinin atfettiği değere ve sahibine karşı gelenekten gelen teamül gereği saygılı olmalarına rağmen onu eleştirmeleri, hakikat arayışı ve ilme verilen değer ile izah edilebilir. Objektif, nazik ve demagojiden uzak bir şekilde yapılan tartışmalar, Arap dil felsefesinin erken dönemde oluşmasına da katkı sağlamıştır.

Gramer konularının manzum anlatımı, kafiye ve veznin uyumundan dolayı, şairi kolay anlatılabilecek konuların zor anlaşılmasına sebep olacak ifadeler kullanmak zorunda bırakmıştır. (Ebû Hayyân, Menhecu's-sâlik, I/1)

Yapılan eleştirilere üslup açısından bakıldığında her ne kadar eleştirilerin bazen dozu artsa da şârihlerin insaf dairesinde olması gerektiğine dair kanaatin sınırlarını zorlayan bir eleştiride bulunmadığını söylemek mümkündür. Nitekim Ebû Hayyân, حرى fiilinin Arap dilinde mukarebe fiili olarak kullanım örneğinin hiçbir sözlükte bulunmadığı ve nahiv kitaplarında bu anlamda yer almadığını ifade ettikten sonra "belki müellifin bizim de bilmediğimiz bir bildiği vardır" demesi küçük bir özür olarak değerlendirilebilir. (İbn Câbir, Şerhu İbn Câbir, II/10)

\section{1. İbn Mâlik’e yönelik metodolojik eleştiriler}

\section{1. İbn Mâlik’in görüşlerindeki tutarsızlıklar}

İbn Mâlik'e yönelik en sert eleştiri, görüşleri arasında tutarsızlık olduğu eleştirisidir. Şairin vezin veya kafiye gereği bir beyitte ifade ettiği bir görüşün Elfiyye'nin başka bir beytinde tamamlanmış olması veya ifade edemediği bir görüşe diğer eserlerinde değinilmesi çoğunlukla şârihler tarafından çelişki olarak değerlendirilmiştir.

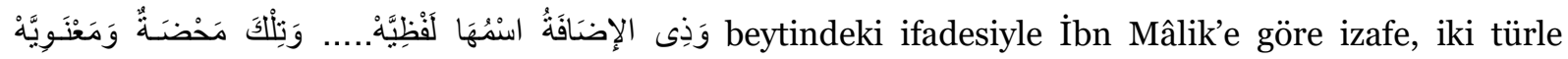
sınırlanmasına rağmen Teshîl'de شبه المحضة adıyla üçüncü bir izafe türü olduğunu söylemesini bu kabilden bir tutarsızlık olarak değerlendirmek mümkündür. (el-Eşmûnî, Şerhu’l-Eşmûnî, II, 306)

İbn Mâlik'in bütün çelişkileri bu kadar masum değildir. Örneğin el-Miknâsî, eş-Şatıbî'den naklederek

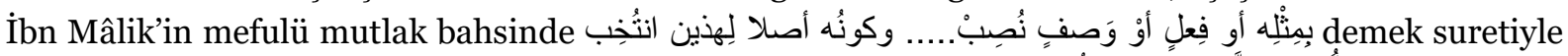

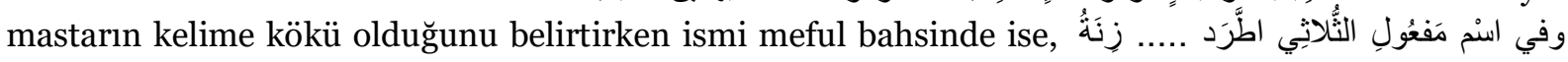
ismin fiilden türediğini belirtmesini en hafif tabirle tesahül olarak değerlendirilmiştir. (el-Miknâsî, Şerhu'l-Miknâsî, II, 160) 


\subsubsection{Elfiyye'deki görüşleri arasında tutarsızlık}

İbn Mâlik, Cumhurdan farklı olarak isnadı, manevi/hakiki ile lafzi/vaz’i olmak üzere ikiye ayırmıştır. Ona göre birinci anlamla isnad, isme has iken ikinci anlamla isnad, kelimenin üç türü arasında müşterektir. قد حرف تحقيق , كتب فعل ماضrneklerinde ise fiil ve harf kendisine isnad edilen

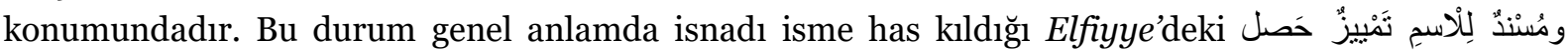
ifadesiyle çeliştiği için Ebû Hayyân ve el-Murâdî gibi şârihler tarafından eleştirilmiştir. (Ebû Hayyân, Menhecu's-sâlik, I/49; el-Murâdî, Tevdîhu'l-makâsıd, I/286,287)

Hâlid el-Ezherî ise İbn Mâlik'in tutarsızlığıyla ilgili verdiği bir örnekte (el-Ezherî, en-Nebîl, II, 16) tesniyelerin tekîdinin علن velimelerinin dışında müzekkerde sadece كلا veleneste de sadece kelimeleri ile yapılabileceğini ifade etmesine rağmen (İbn Mâlik, Şerhu't-teshîl, 1990, III, 290) bir sayfa

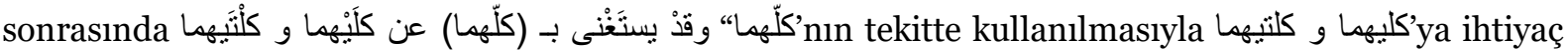
kalmayabilir” ifadesiyle önceki görüşünden farklı görüş ortaya koyduğunu belirtmiştir.3 İbn Akîl de bu

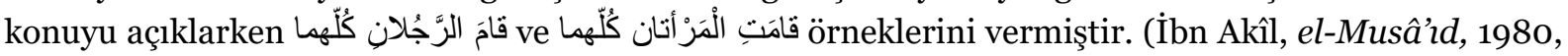
II, 387) Tutarsızlık eleştirisinin yöneldiği nokta şöyle izah edilmiştir: Her hâlükârda İbn Mâlik vل ve كلت كل kelimesinin onların yerine kullanılabileceğini söylemesi gerekirdi. (el-Ezherî, Muvassllu'n-nebîl 1998, III, 1019)

\subsubsection{Elfiyye ile diğer eserlerindeki görüşleri arasında tutarsızlık}

Şârihlerin bu türden itirazları, genellikle İbn Mâlik'in Elfiyye'deki görüşleri ile başta et-Teshîl olmak üzere diğer eserlerindeki görüşleri arasında bir çelişki olduğu yönündedir.

\subsubsection{Tahsisten kaynaklanan tutarsızlıklar}

İbn Mâlik'e göre ال ما Sen ne kararına rıza gösterilecek bir hakemsin,

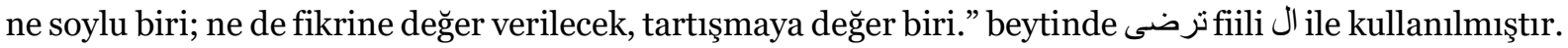
(İbn Mâlik, Şerhu kâfiyeti’s-şâfiye, s. 163) İsme özgü olan ال ise yalnızca tarif edatı olarak kullanılır. Şerhu kâfiyeti'-ş-şâfiye'de ismin özelliklerini sayarken ال takısını değil, harf-i tarifi esas alması ve mevsule olanın bundan farklı olduğu düşüncesi her ne kadar aynı eser içerisinde çelişki sayılmasa da

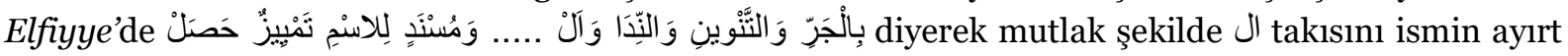
edici özelliklerinden sayması eleştirilmiştir. (s. 165) el-Murâdî el-Miknâsî gibi şârihler ال takısının marifelik için kullanıldığı gibi mevsule olarak kullanılmasının İbn Mâlik tarafından da kabul edilmiş olmasının böyle bir tahsisten kaçınması için yeterli olduğunu vurgulamışlardır. (el-Murâdî, Tevdîhu'lmakâsıd, I/284; el-Miknâsî, Şerhu'l-Miknâsî, I/175) Tahsisin sebep olduğu bu çelişki isme ait

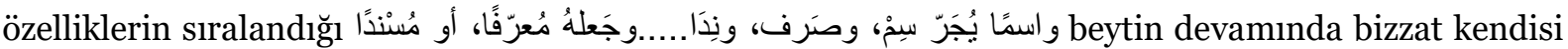

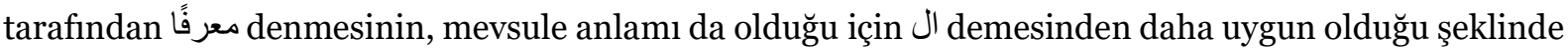
açıklanması, sonra yazılmasına ve aradaki farkı göstermek adına yapıldığı intibaını uyandırmasına rağmen, Elfiyye'deki ifadesi tutarsızlık eleştirisinden kurtulamamıştır.

Arap dilinde ال ile mârife olan bir ismin münâdâya atıf olması durumunda lafzı dikkate alınarak merfû,

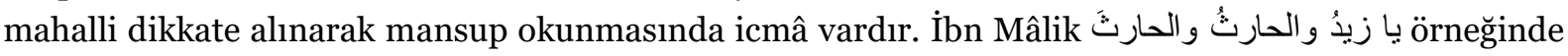

\footnotetext{
$2 \quad$ Elfiyye şârihlerindendir. Eserinin iki ayrı tahkiki yapılmıştır. Mısır'da yapılan tahkikte eserin ismi en-Nebîl ilâ Nahvi'tTeshîl, Ümmü'l-Kurâ Ünv. Arap Dili Fakültesi’nde yapılan tahkikte Muvassılu'n-Nebîl ilâ Nahvi't-Teshîl șeklindedir.

İbn Mâlik bu konuda mahalli şâhid kullanmamıştır. Konunun ihtilaflı olması ve şahit getirememiş olması belki de elEzherînin bu açı̆̆ı yakalamasına sebep olmuştur.
} 
olduğu gibi bunun iki şekilde okunacağını ifade ettikten sonra başında takısı olmayan atıfların da el-

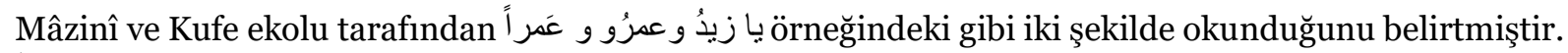

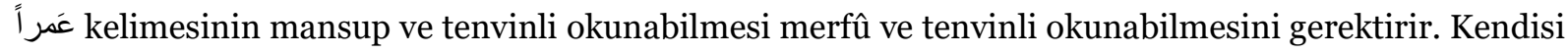
de bu görüşün nidâ harfinin tekrarına niyet edilmediğinde "doğrudan uzak bir görüş" olmadığını söylemiştir. Nitekim حَسِبْتُ زَيْدًا وَ عَمْرًا حَاضِرَين "Zeyd ve Amr’n geldiğini zannettim” örneğinde nasıl ki âmil iki ismi de etkilemişse burada da böyle bir kastın aranması mümkündür. (İbn Mâlik, Şerhu’t-teshîl, III, 402)

Hâlid el-Ezherînnin eleştirisi de tam bu noktadadır. Zira İbn Mâlik Kâfiye’sinde,

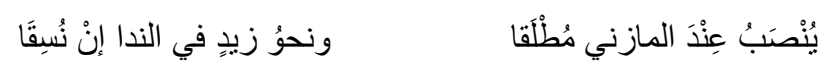

el-Mâzinîye (ö. 249) göre atıf durumunda Zeyd kelimesinin mutlak olarak mansup olacağını ifade etmektedir. (el-Ezherî, Muvasslu’n-nebîl, III, 1181)

\subsubsection{Efrâdını câmi olmayan ifadeden kaynaklanan çelişkiler:}

İbn Mâlik konusunu anlatırken حَقُّه النَّْنبُ و قدُ يجرُ بِباعٍ زائِدة ifadesiyle hal'in mansup olduğunu fakat zaid bir harfi ceri ile mecrur da olabileceğini ifade etmiştir. (İbn Mâlik, Şerhu't-teshîl, II, 321) Fakat

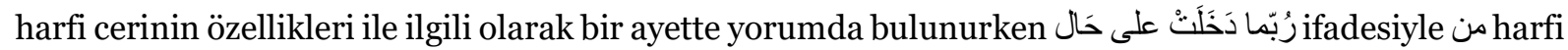

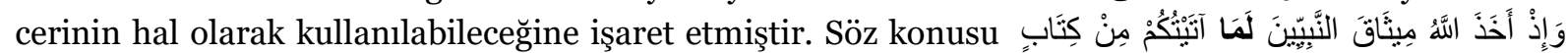

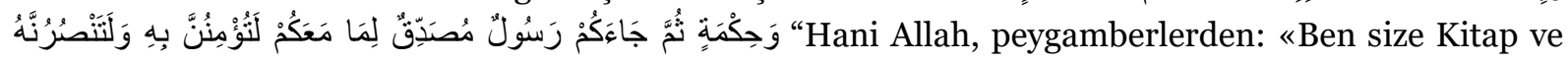
hikmet verdikten sonra nezdinizdekileri tasdik eden bir peygamber geldiğinde ona mutlaka inanıp yardım edeceksiniz» diye söz almıştı" (Âl-i İmrân, 3/81) ayetini izah ederken lل şeklindeki okumanın aslında مِ ve v'dan müteşekkil olduğunu ve idgam yapıldığında ortaya çıan üç mim'den birinin mahzuf

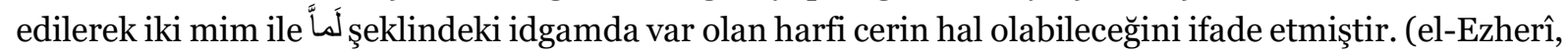
Muvassllu'n-nebîl, II, 659)

Konusu anlatılırken çizilen sınırlar içerisinde harfi cerlerden ancak ب ب ile yapılabileceği takyîd edilen hal, من ile ilgili ihtimal dâhilinde bir istisnanın varlığı ile yapılan sınırlandırmaya itirazı doğurmuştur.

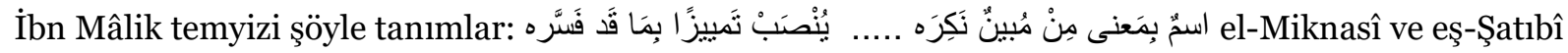

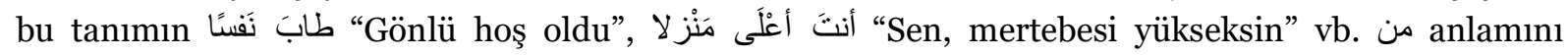
barındırmayan temyiz türlerini kapsamadığı gerekçesiyle efradını cami bir tarif olmadığını belirtmişler. (el-Miknâsî, Şerhu’l-Miknâsî, II, 120) Nitekim nâzımın kendisi de ilerleyen beyitlerde bazı temyiz türlerinde من harfinin kullanılamayacağını belirtmek suretiyle bütün temyiz örneklerinde من harfinin anlamının bulunamayacağını ifade etmiştir:

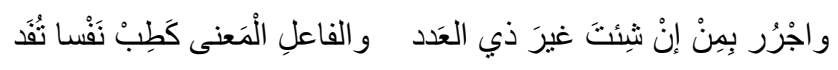

\subsubsection{Zaruret-i şi'riyyeyi istisna kılmasından kaynaklanan çelişkiler}

İbn Mâlik’in bir konuyu anlatırken yaptığı sınırlandırmalarla ilgili olarak aldığı eleştirinin bir diğeri ise

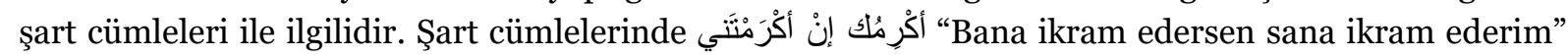

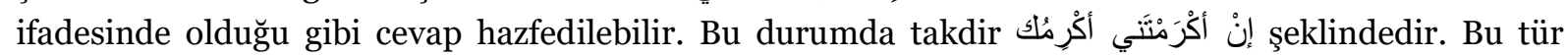
ifadelerde افعل هذا، و إلا ضربتأك "Bunu yap, değilse seni döverim” cümlesinde olduğu gibi şart cümlesi de

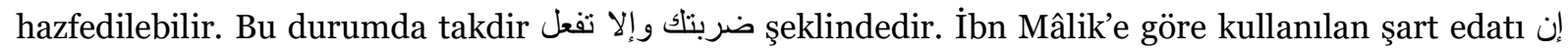
olmak kaydıyla zarûrât-ı şi'riyyeden sayılarak şart ve cevap cümleleri mahzuf olabilir. (İbn Mâlik, 
Teshîlu'l-fevâid, s. 239) eş-Şâtıbî’nin çok nadiren olduğu için İbn Mâlik'in üzerinde durmadığını ifade ettiği (eş-Şâtıbî, el-Makasıdu'ş-şafiye, 2007, VI, 163) bu konuda kendisine yöneltilebilecek eleştiri ise şart ve cevap cümlelerinin birlikte hazfini şiire ve إن edatına takyîd etmesine yönelik olacaktır.

Örneğin Hâlid el-Ezherî delil olarak şu hadisi zikreder:

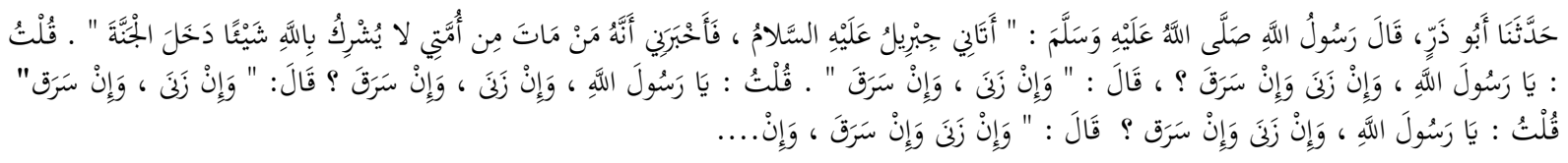

Ebû Zer el-Gıfari (r.a.) anlatıyor: "Hz. Peygamber Efendimiz "Cebrail bana geldi ve ümmetimden hiçbir şeyi Allah'a şirk koşmadan ölen kimsenin cennete gireceğini haber verdi” buyurdu. (Hayretle) dedim ki: 'Zina etse ve hirsızlık yapsa da mı?' Cevaben: 'Evet, zina etse ve hirsızlık yapsa da!' dedi. (Ben hayretimi yenemeyerek yine) dedim ki: 'Zina etse de hirsızlık yapsa da mı girer?' Resûlullah (sav.) yine: “(Evet) Zina etse de hırsızlık yapsa da (o kul cennete girecektir)" buyurdu.” (Buhârî, Tevhid-33; Muslim, İman153; Tirmizî, İman-18)4 Benzerine başka hadislerde de rastlanılan (Abbas Hasan, en-Nahvu'l-vâfí, IV, 481) bu ifadenin son kısmında Rasûlullah (sav.) şart edatını şart ve cevap cümlesini hazf ederek kullanmıştır.

Bu durumun, sadece إن ile tahsis edilmesinin hatalı olduğunu da şu beyit göstermektedir:

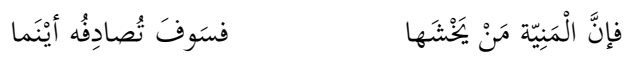

"Kim ölümden korkarsa o onu bulacaktır ve her nereye (kaçarsa onu yakalayacaktır.)" Bu beytin sonundaki أينما'nın şart ve cevap cümleleri mahzuftur. Takdiri ise أينما يذهبْ تصادفُ şeklindedir. (el-Ezherî, en-Nebîl, II, 714; eş-Şâtıbî, el-Makasıdu'ş-şafiye, VI, 163; Abbas Hasan, en-Nahvu'l-vâfí, IV, 481)

İbn Mâlik et-Teshîl'de muttasıl zamirin إلّا dan sonra gelmesinin şaz olduğunu söylerken Elfiyye'deki

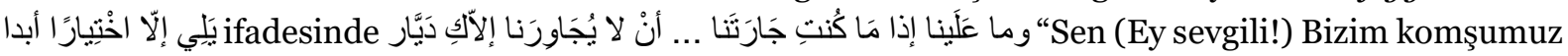
olursan senin dışındaki herkesin komşuluğundan bize ne gerek” şahidinde olduğu gibi zaruret-i şi'riyyede gelebileceğini ifade etmesi tutarsızlık olarak değerlendirilmiştir. (İbnu’n-Nâzım, Şerhu İbni’nNâzım, s. 34; (el-Murâdî, Tevdîhu'l-mekâsıd, I, 361)

\section{2. İcmâ olan konulardaki problemler}

İbn Mâlik'e yönelik bu başlık altında ele alınabilecek eleştiriler az denemeyecek sayıdadır. Cumhurun görüşlerini bazen özellikle kabul etmediğini ifade eden İbn Mâlik, bazen sadece farklı görüşünü serdetmekle yetinmiştir. Yerine göre gözünden kaçırdığını düşündüren bu farklı görüşlerin yaygın kullanımı olan veya az bir nahiv eğitimi alan kişinin bileceği konular olması tek bir yargıya sahip olmaya engel teşkil etmektedir. Örneğin Cumhura göre işaret isimlerinde yakın, orta ve uzak olmak üzere üç mertebe varken İbn Mâlik'te iki mertebe söz konusudur. Ona göre orta yoktur. Onun bu yaklaşımı Ebû Hayyân tarafından acımasızca eleştirilmiştir. (Ebû Hayyân, Menhecu's-sâlik, I/24) Aynı şekilde Elfiyye şârihlerinden dokuzu her ne kadar anlamaya çalışarak bu fikre açılkama getirmiş olsalar da İbn Mâlik’i beytinde marife isimleri, zamir, işaret ismi, özel isim, marifeye muzaf, ال و takısı alan isim ve mevsul isim olmak üzere altıyla sınırlandırmasından dolayı

$4 \quad$ Hadis-i şerif özetlenerek verilmiştir. 
eleştirmiştir. Nitekim münada-i maksudun marife olduğunda icmâ vardır. İbnu'n-Nâzım, Şerhu İbni’nNâzım, I, 33; İbn Hişâm, Evdahu'l-mesâlik, I, 83)

İbn Mâlik'e yönelik bu türden eleştirilerde sadece onun kullandığı, o güne kadar kullanılmamış yeni kelime, tanım ve tabirlerin de etkisi vardır. Örneğin İbn Mâlik, حرى fiilini mukarebe fiillerinden

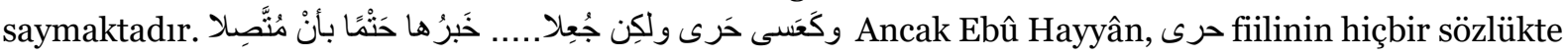
bu anlamda kullanılmadığını ve bu fiilin Arap dilinde mukarebe fiili olarak kullanım örneğinin bulunmadığını iddia ederek bu görüşün İbn Mâlik'in nevi şahsına münhasır olduğunu söylemiştir. (Ebû Hayyân, Menhecu's-sâlik, I/69)

İbn Mâlik'in farklı bir şey söyleme gayreti olarak değerlendirilebilecek olan ve meselenin anlaşılmasını kolaylaştıran bazı sınıflandırmaları da icmanın dışına çıktığı iddiasıyla eleştirilmiştir. Örneğin İbn

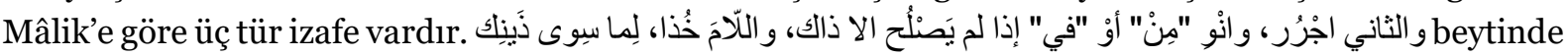

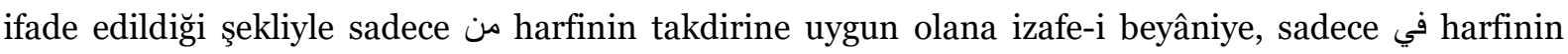
takdirine uygun olana izafe-i zarfiyye, في ن veya في في harflerinin takdirine uygun olmayan diğer bütün izafe türlerine de izafe-i lâmiyye denir. İbn'u-Nâzım babasının bu görüşüne yer verdikten sonra Sibeveyh ve muhakkik dilcilerin çoğunluğunun bu görüşü benimsemediğini onlara göre lâmiye ve beyâniye olmak üzere sadece iki tür izafe olduğunu belirtir ve gerekçelerini sıralar. Aynı şekilde İbn Câbir de dilcilerin çoğunun izafe-i zarfiyye diye bir izafe türünü kabul etmediğini, İbn Mâlik’in izafe-i zarfiyye dediği bu türü izafe-i lâmiyye kısmına dâhil ettiklerini belirtmiştir. İbnu'n-Nâzım, Şerhu İbni”n-Nâzım, s. 272274.

\subsubsection{Cumhura muhalefet edilmesi}

İbn Mâlik Elfiyye'de Cumhura olan muhalefetini yer yer açlkça ifade emektedir. Nitekim Cumhura açıkça muhalefet ettiği yerlerden zamir bahsinde,

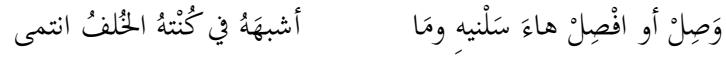

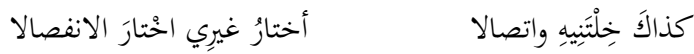

ifadeleriyle mansub ardışık zamirlerin bitişik veya ayrık gelmeleri ile ilgili bölümde yer alan bu beyitlerde Cumhurdan farklı olarak كان gibi nakıs fiillere bitişen zamirlerden ikincisinin de muttasıl gelebileceğini açıkça ifade etmektedir. Ebû Hayyân İbn Mâlik'i bu hususta acımasızca eleştirerek onun bu görüşünün Sibeveyh’in Araplardan naklettiği sağlam örneklerle örtüşmediğini, İbn Mâlik’in bu görüşünü tamamen yapay ve zayıf örneklerle temellendirdiğini ifade etmiştir. Bu eleştiride her ne kadar

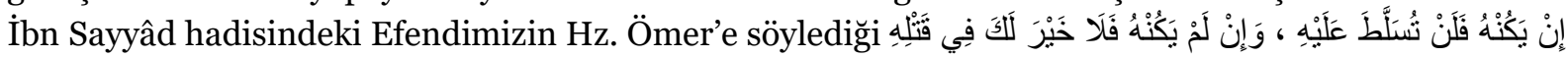
"Eğer o (İbn Sayyad) o (düşündüğün) ise gücün yetmez. O değilse zaten öldürmeye değmez." ifade delil olarak getirilmiş olsa da İbn Hişâm, İbn Akîl ve el-Murâdî gibi büyük şârihler de bu konuda İbn Mâlik’i Cumhura muhalefetten dolayı eleştirmişlerdir. (el-Murâdî, Tevdîhu'l-mekâsıd, I, 373; Ebû Hayyân, Menhecu's-sâlik, I/18; İbn Hişâm, Evdahu'l-mesâlik, I, 97-99; İbn Akîl, Şerhu İbn Akîl, I, 104)

İbn Mâlik mansup munfasıl zamirlerin te'kid olarak kullanılamaması konusunda da üzerinde icmâ olan

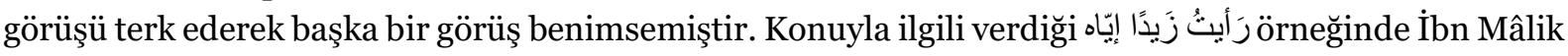
şunları ifade etmektedir: "Ben müelliflerin birbirlerini taklit ederek aynı örnekleri kullanmaları sebebiyle bu örneği verdim. Bana göre Araplar bunu ne nazımda ne de şiirde kullanmışlardır. Kullanılmışsa da te'kid olur, bedel değil.” (el-Ezherî, Muvassılu’n-nebîl, III, 332) İbn Mâlik bunun ancak "idrab ifade etmemesi” kaydıyla mümkün olacağını da bu görüşe ilave etmiştir. 
İbn Mâlik, bu düşüncesiyle “zahir isim zamirle te’kid olunmaz" fehvasındaki icmâya muhalif bir düşünce ortaya koymaktadır. Kaldı ki kendisi de bu kullanımın Araplarda olmadığını ifade etmiştir. Olmadığını ifade ettiği görüşünü zaten izahı mümkün olmayan bir görüssle ve te'kidin zamirle yapılamayacă̆ına dair Cumhurun kanaatine rağmen bu şekilde izah etmiş olması da şârihleri tarafından eleştirilmiştir. Zira elMuberred, İbn Cinnî, ez-Zemahşerî gibi dilciler bunu bedel olarak kabul etmektedir. (el-Muberred, elMuktedab, IV, 296; İbn Cinni, el-Lem' fi'l-Arabiyye, 88; ez-Zemahşerî, el-Mufassal, s.158) Ayrıca elEzherî idrab ifade etmemesi durumundaki kaydını da doğru kabul etmez. Zira bu durumda zaten te'kid değil bedeli idrab olacaktır. (el-Ezherî, Muvassılu’n-nebîl, III, 1079)

Bu konuya örnek olabilecek diğer bir mesele de terkîb-i mezcîlerle ilgili görüşüne yönelik eleştiridir. İbn Mâlik مفاعيل vezniyle biten terkibi mezcileri alem olmadıkları durumlarda da gayri munsarif olarak kabul etmiştir. Bizzat kendisinin de icmânın dışında olduğunu ifade ettiği bu görüş bazı dilciler tarafından kabul görmemiştir. (İbn Mâlik, et-Teshîl, s. 221; İbn Kayyım İrşadu’s-salik, II, 747) Zira bu kelimeler nekra oldukları durumunda alem sayılmazlar. Bu durumda da gayrı munsarıf konusundaki gerekli şartları taşımamış olurlar. (el-Ezherî, en-Nebîl, II, 526)

Diğer bir konu da hâl'in harfi cer ile mecrur olan sahibu'l-hâle takdimi meselesidir. Örneğin جَالََِِة "Hind'e otururken uğradım." cümlesinde جالسة hâl'inin sahibu'l-hâl olan Hind’in önüne geçmesi

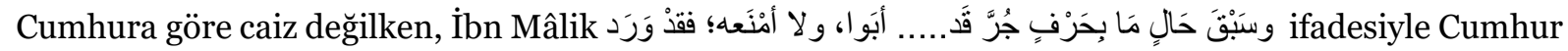
kabul etmese de bana göre caizdir demektedir. Bu tutumu, şârihler tarafından eleştirilmektedir. İbn Akîl, Şerhu İbn Akîl, I, 235; İbn Câbir, Şerhu İbn Câbir, II, 304.)

\subsection{2. İcmaya nisbet ettiği görüşlerdeki problemler}

İbn Mâlik'in icmâya nispet ederek aktardığı bazı konularda, icmânın dışında tutulması mümkün olmayacak bazı dil âlimlerinin Cumhur ile aynı görüşte olmadığı için söz konusu meselede tam bir icmâdan söz etmek mümkün değildir.

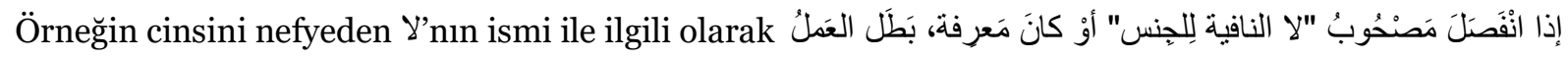

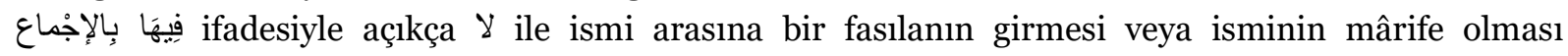
durumunda cinsini nefyeden لَ'nın amel edemeyeceğini icmâya dayandırarak açıklamıştır. (İbn Mâlik, Şerhu't-teshîl, II, 64) Hâlbuki er-Rummânî araya bir fasılanın girmesi durumunda da لע كذلك رجلا لا örneğinde olduğu gibi ismini nasp edeceğini ifade etmektedir. (es-Suyûtî, Hem'u'l-hevami, I, 526) Hakeza Kufe ekolüne göre У'nın isminin alem olduğunda fetha üzere mebnî olması da bu konuda tam bir icmâ olmadığını göstermektedir. (el-Ezherî, en-Nebîl, I, 425)

İcmâya nispet edilen görüşlerdeki problemlere örnek olabilecek olan ikinci mesele ise temyizin, âmilinin önüne geçmesi meselesidir. el-Kisâî, el-Mâzinî ve el-Muberred'in sadece âmilin mutasarrıf fiil olması durumunda kabul ettikleri bu görüş (el-Muberred, el-Muktedab, III, 36; İbn Akîl, II, 65; Ebû Hayyân, İrtişafu'd-darab, 1984, II, 384; İbn Hişâm, Evdahu'-mesâik, 1994, II, 372) İbn Mâlik tarafından da benimsenmiş (İbn Mâlik, Şerhu't-teshîl, II, 390), âmilin mutasarrıf olmayan bir fiil olması durumunda 5 ise takdimin olamayacağı icmâya bağlanmıştır. (el-Ezherî, Muvassılu'n-nebîl, II, 719-721) Hâlbuki Ebû Hayyân ve Hâlid el-Ezherî̀ye göre el-Ferrâ gibi bir dil bilimci, mutasarrıf olmayan bir fiil olması durumunda da temyizin takdimini caiz görmesine rağmen bu görüşün icmâya dayandırılmış olması bir

el-Ezherî âmilin mutasarrıf fiil olması durumunda temyizin takdimini kabul etmeyen Sîbeveyh’e de şu beyitle karşıllı

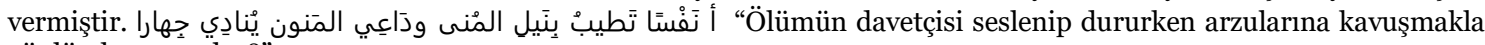
gönlün hoş mu olur?” 
hatadır. (Ebû Hayyân, II, 384; İbn Akîl, II, 67; el-Ezherî, Muvassllu’n-nebîl, II, 719-721) Zira زيد القمر "Zeyd güzellik bakımından Ay gibidir” ifadesindeki gibi bir teşbih varsa müşebbeh bih'in (benzetilen) haber olması şartıyla temyiz olan حسنا kelimesinin زيد حسنا القمر şeklindeki takdimi caizdir. (el-Ezherî, Muvassılu’n-nebîl, II, 719-721)

İbn Mâlik cem-i müennes nûnu bitişen muzârî fiilinin ittifakla mebni olduğunu iddia etmiştir. elMurâdî, bu hususta farklı düşünen ve muzârî fiilin bu durumda da mu'rab olduğunu ifade eden dilcilerin bulunduğunu söyleyerek icmaya nispet edilen bu görüşte problem olduğunu tespit etmiştir. (el-Murâdî, Tevdîhu'l-mekâsıd, I, 306)

\section{3. Şâz ve merdûd görüşlere yer verilmesi}

İbn Mâlik, i'lalden veya meczum olmasından dolayı harf sayısı teke veya ikiye inen fiillerin sonuna vakıf esnasında هاء السكت bitişmesi gerektiğini şu beyitlerinde ifade etmektedir.

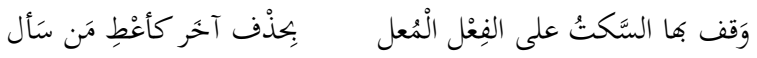

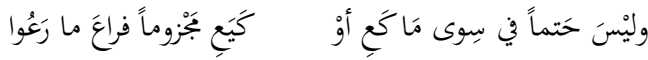

İbn Hişam, İbn Mâlik'in وعى وعيَعْهُnin biilinin muzarisi zaid olan iki harf olduğu için hâu's-sekt

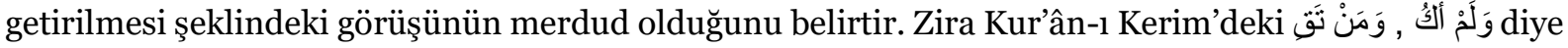
başlayan ayetlerde (Meryem, 19/20; el-Mümin, 40/9) vakıf esnasında hiçbir kıraatta vakıf hâsı getirilmemiştir. İbn Kayyım da aynı gerekçeyle İbn Mâlik’in bu görüşünün büyük bir yanılgı olduğunu ifade etmiştir. (İbn Hişâm, Evdahu'l-mesâlik, IV, 349; İbn Kayyım, İrşâdu’s-sâlik, II, 967)

واذِ ابنَكَى ابْر اهِيَ ربُهُ "İbrahim'i Rabbi imtihan etti." (el-Bakara, 2/124) ayetinde olduğu gibi, mefule dönen muttasıl bir zamir, faile bitiştiğinde mefulün takdimi, failin te'hiri vaciptir. Çünkü gaib zamirin lafzen ve rütbeten müteahhir bir isme irca'ı caiz değildir. (el-Murâdî, Tevdîhu'l-mekâsıd, I, 102; İbn Hişâm, Evdahu'l-

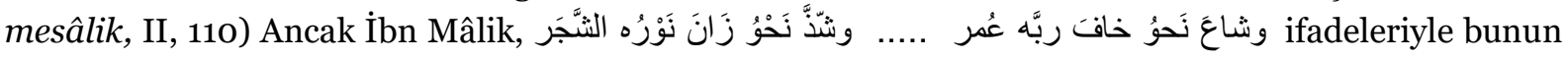
aksinin şaz da olsa caiz olduğunu belirtmiştir.

\subsection{Tercih veya görüşlerinde isabetsizlik}

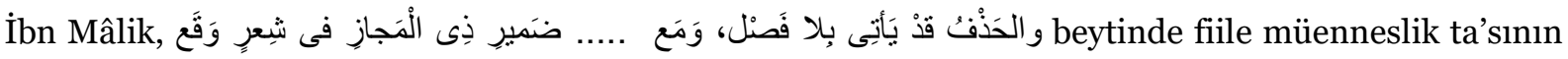
zorunlu olarak bitişmesi için gerekli şartların olduğu veya fiille fail arasında fasılanın olmadığı durumlarda bile bazen tâu't-te'nîsin düşebileceğini belirtmektedir. İbn Mâlik'in, Sîbeveyhi'nin Araplardan şâz diyerek naklettiği, sadece فالَ فُلانُّ vb. semai örneklerle sınırlı olan ve kıyası mümkün olmayan böyle bir kullanımı normal bir kullanım gibi sunması şârihler tarafından isabetsiz bir görüş

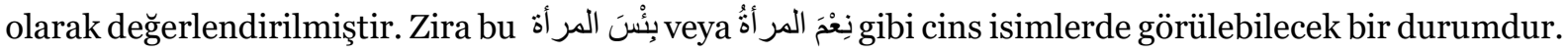
(İbn Hişâm, Evdahu'l-mesâlik, II, 112)

İbn Mâlik’in isabetsiz görüşleri sadedinde mansub ardışık zamirlerin sıralaması ile ilgili bölümde

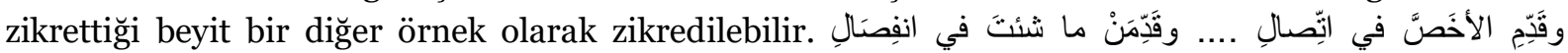
ifadesinden de anlaşıldığı üzere ikinci sırada getirilecek olan zamir munfasıl zamirse, zamirler arasındaki marifelik hiyerarşisi gözetilmeksizin ikisinden biri öne alınabilir. Ancak bazı şârihler bu durumun mutlak bir şekilde söz konusu olmadığını, yalnızca iltibas olmayan yerlerde mümkün 
olduğunu söylemişler. Örneğin زيد أعطينك ايّاه cümlesinde, muhayyerlik durumunda زيد أعطيته إياك şlinde iltibas olacağı için mefuller arasında yer değişikliği yapılamaz. (İbn Akîl, Şerhu İbn Akîl, I, 107)

\section{Diline ve üslubuna yönelik eleştiriler}

\subsection{Eksik birakılan tanımlar}

İbn Mâlik'in şârihleri tarafından eleştirildiği en önemli konulardan biri tanımlardır. Bazı konularda

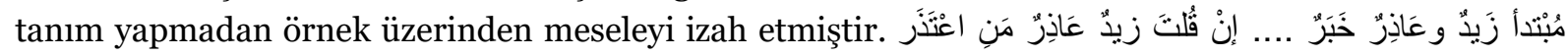
beytinde olduğu gibi mübteda ve haber konusunu işlerken hiçbir tanım yapmaksızın konuyu örnekler üzerinden işlemesi Ebû Hayyân'ın eleştirilerinden nasibini almıştır. (Ebû Hayyân, Menhecu's-sâlik, $\mathrm{I} / 36)$

İbn Mâlik bazen de zaruret-i nazımdan dolayı tanımdaki bazı kayıtları örneklerle ifade etmiştir. Örneğin

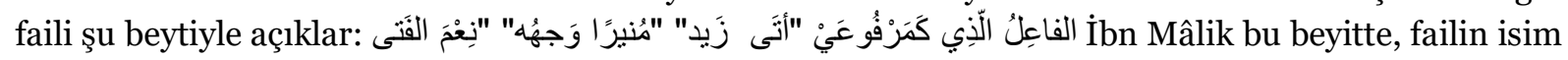
olmasını, merfu olmasını, mutasarrıf veya camid fiilin yanı sıra müştak isimlerin de fail alabileceğini ifade ederken aynı zamanda failin amilinden sonra gelmesi gerektiğine de dikkat çekmiştir. Ancak bu beyit müevvel isimden oluşan faili kapsamamaktadır. Bu durum şârihler tarafından eleştirilmiştir.

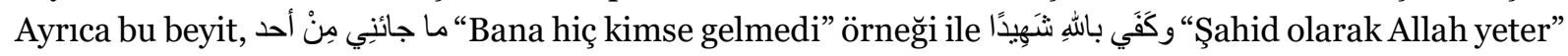
(el-İsra, 17/96) örneğinde olduğu gibi zaid harfi cerle mecrur olan failleri de kapsamamaktadır. Her ne kadar söz konusu eksikliğe işaret eden es-Suyûtî, merfu kaydını lafzi veya mahalli diye tamim ederek çözüm yolu bulmaya çalışmış olsa da (es-Suyûtî, el-Behcetu'l-merdıyye, I, 199) İbn Câbir konu üzerinde hassasiyetle durmuştur. (İbn Câbir, Şerhu İbn Câbir, II, 117, 118)

\subsection{Tanım tekniği açısından problemler}

\subsubsection{Devre düşen tanımlar}

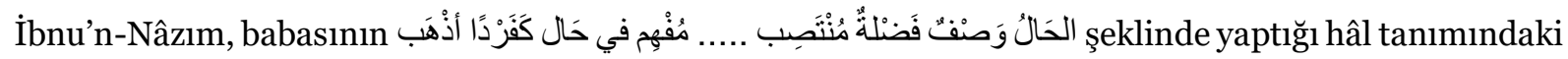
kelimesini, hüküm barındırdığından dolayı eleştirmiştir. (İbnu’n-Nâzım, Şerhu İbni’n-Nâzım, 227, 228) Zira hükmün tanımda yer alması devre yol açttğından tanım tekniği açısından makbul

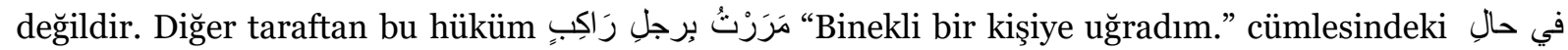
şُ رُكُوبه açılar: Halin mansup olmasına dair olan tanımlama (منتصب) bir hükümdür. Hüküm tasavvurun bir cüzüdür ve ona bağlıdır. Yani herhangi bir varlık hakkında hüküm verebilmemiz için sahip olmamız gereken tasavvurî bilgi, tanıma bağlı olduğu için hükmün tanımda yer alması kısır döngüye (devr) sebep

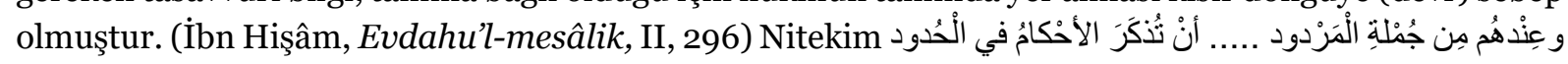
ifadesi de bunun izahı niteliğindedir.

İbnu'n-Nâzım'ın bu eleştirisine katılan İbnu'l-Verdî, beytin şu şekilde düzeltilmesini önerir:

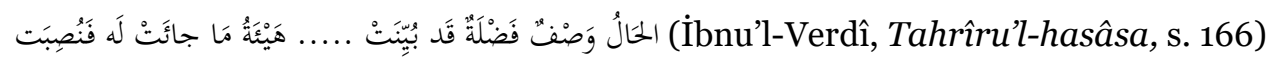

Devrin sebep olduğu tanım hatasına daha rahat anlaşlabilecek bir örnek olarak İbnu'n Nâzım'ın benzer bir itiraz yaptığı sıfatu'l-müşebbehe tanımında görmek mümkündür. Şöyle ki İbn Mâlik sıfatu'l-

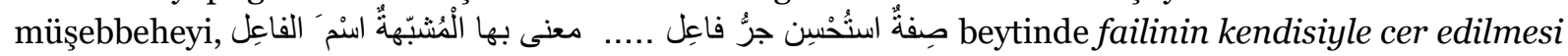
güzel olan sıfat (müştak isim) şeklinde tanımlamıştır. İbnu'n Nâzım da sıfatı müşebbehenin, kendisine ait bir hükümle tanıtılmasının tanım tekniği açısından devre sebebiyet verdiğini, dolayısıyla bunun 
doğru bir tanım olmadığını belirtmektedir. Zira failinin kendisiyle cer edilmesi sıfatu'l-müşebbeheye ait bir hükümdür ve bu hükmün tanımda yer alması doğru değildir. (İbnu'n-Nâzım, Şerhu İbnu'n-Nâzım, s. 318)

\subsubsection{Efrâdını câmî ağyarını mani olmayan tanımlar}

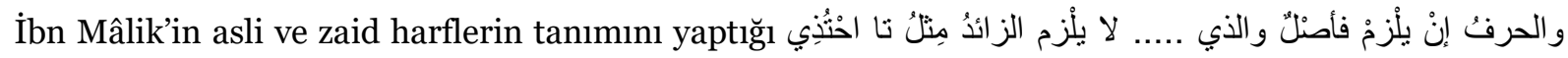
beyti, İbn Hişam ve İbn Kayyım tarafından eleştirilmiştir. Zira buna göre kelimeden düşebilen harfler zaid, düşemeyenler ise asli harflerdir. Hâlbuki كوكب kelimesindeki و düşmediği hâlde zaid, وعد kelimesindeki و düştüğü hâlde asli bir harftir. Dolayısıyla buradaki tanım efradını cami ağyarını mani bir tanım değildir. (İbn Hişâm, Evdahu'l-mesâlik, IV, 364; İbn Kayyım, İrşâdu's-sâlik, II, 992)

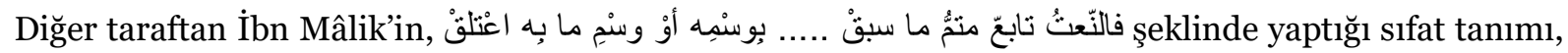
ağyarını mani olmak hususunda başarılı görülürken medih veya zem için gelen sıfat türlerini kapsamadığından efradını cami bir tanım olmadığı gerekçesiyle İbn Hişâm vb. şârihler tarafından eleştirilmiştir. (İbn Hişâm, Evdahu'l-mesâlik, III, 300)

Konuyla ilgili biraz daha farklı bir eleştiri İbn Mâlik’in و الخبرُ الجُزءُ الْنتمّ الفاءدة şeklindeki haber tanımına gelmiştir. Cümleyi anlamlı kılmak suretiyle tamamlayan yegâne unsur haber olmadığı için tanım kusurlu görülmüştür. (Ebû Hayyân, Menhecu's-sâlik, I/38)

\subsection{Eksik bilgi verilen konular}

Şârihlerin bu türden eleştirilerinin yoğun olduğu görülmektedir. Ancak bu eleştirilerin geneline bakıldığında şârihlerin yer yer haklı oldukları durumlar olsa da çoğunlukla şaire haksızlık yaptıkları aşikârdır. Zira eksik olduğu şeklinde yapılan eleştirilerin pek çoğunda İbn Mâlik’i eleştirdikleri bilgi, değil manzum bir metinde ancak bir şerh veya bir haşiyede yer alabilecek türden detay bir bilgidir. Nitekim İbn Mâlik, Elfiyye’nin mukaddimesinde مقاصِدُ النّحوِ بها محْوِية ifadesiyle nahiv ilminin ana konularının yer alacağını ifade etmiştir.

Şârihlerin birkaç örnekle yetineceğimiz bu türden itirazlarını hemen her konu başlığı altında bulmak mümkündür. Örneğin izafe konusunda lafzi ve manevi izafeyi anlattıktan sonra manevi izafenin tersine lafzi izafenin marifelik sağlamadığını belirmiştir. Ancak el-Murâdî, İbn Mâlik’in غير, شبه gibi izafe ile marifeleşemeyecek derecede müphem olan kelimeleri ihmal ettiği gerekçesiyle eleştirmiştir. (el-Murâdî, Tevdîhu'l-mekâsıd, II, 790)

Elfiyye'de eksik bilgi verilen konulardan bir diğeri cinsi nefy eden У'dır. Cinsi nefy eden У'nın ismi müfred (muzaf veya şibih muzaf olmayan) olduğunda nasb üzere mebni olur. Yani tekil isimler fetha üzere, cem'i mü'ennesler kesre üzere, tesniye ve cem'i müzekkerler de yâ üzere mebni olur. Bu yüzden

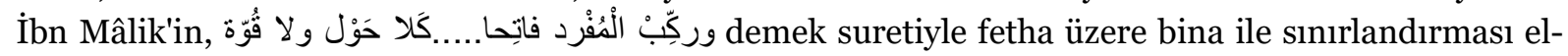
Murâdî tarafından eksiklik olarak görülmüş ve eleştirilmiştir. (el-Murâdî, Tevdîhu'l-mekâsıd, I, 547)

Şârihler içerisinde özellikle bu tür meselelerde İbn Mâlik'e haksızlık yapıldığını düşünerek ona yapılan eleştirilere yanıt vermeye çalışanlar da olmuştur. Çalışmanın konu ve kapsamı gereği aralarındaki bu tür tartışmalara değinmeyeceğimizi ifade ettiğimiz konulardan birinde İbn 'Akil, başta Ebû Hayyân olmak üzere bazı Elfiyye şârihlerinin Elfiyye'deki konusal eksiklik iddialarına savunmacı refleksle yaklaşmıştır. Örneğin İbn Mâlik ن nin hemzesinin kesralı okunduğu yerleri şu beyitlerle açıklar: 


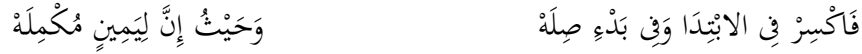

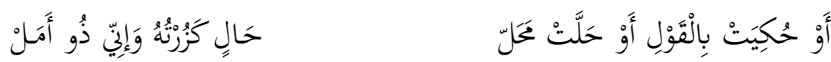

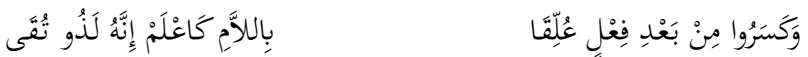

Ebû Hayyân hemzenin kesralandığı yerlerin tamamının burada anlatılmadığını, zikredilen yerlerin dışında da hemzenin kesralandığı yerlerin olduğunu söyleyerek İbn Mâlik’i eleştirirken; (Ebû Hayyân, Menhecu’s-sâlik, I, 75) İbn ‘Akil, Ebû Hayyân'ın sözünü ettiği yerlerin tamamının İbn Mâlik'in في الابندا ifadesi kapsamına dâhil olduğunu, dolayısıyla burada bir eksiğin olmadığını söylemiştir. (İbn Akîl, Şerhu İbn Akîl, I, 354)

Bunların dışında tarif edatının ال أ mi mi olduğu konusunda dört farklı görüş olmasına rağmen İbn Mâlik’in şeklindeki ifadeleri konuyla ilgili yalnızca iki görüşün olduğunu vehmettirmesi, (Ebû Hayyân, Menhecu's-sâlik, I, 33) kasem ile ilgili müstakil bir başlık açmayıp farklı başlıklar altında kasem harflerine ve kasemle ilgili bazı hükümlere yer vermesi eksiklik kabul edilerek yadırganmıştır. (el-Mekkûdî, Şerhu'l-Mekkûdî, II, 721)

\section{4. İfadelerde ta'kîd ve muğlaklık olması}

Elfiyye'nin bazı beyitleri muğlak olması yönüyle eleştirilmiştir. Örneğin في الدّارِ ساكِنُهُ "Evde sahibi var" cümlesinde olduğu gibi haberin mübteda üzerine takdiminin zorunlu olduğu yerlerden birisi de

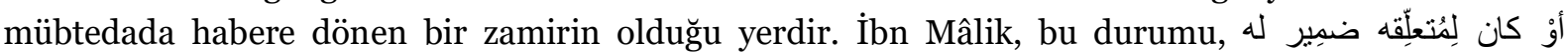
ifadeleriyle beyan eden İbn Hâcib'i, “ibaresi kapalı ve anlaşılmazdır” diye eleştirirken kendisi Elfiyye’de bu durumu daha girift ve anlaşılmaz bir beyitle ifade etmiştir. Nitekim bu muğlaklık es-Suyûtî gibi fazla

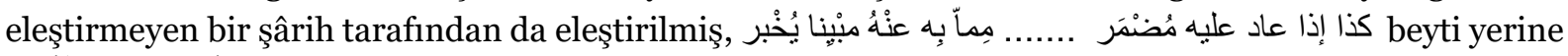
beyti alternatif olarak önerilmiştir.

İştigal bahsinde, عمرو هل رأيته “Amr’ı gördün mü?” vb. örneklerde müştegalu 'anh ismin vücubi olarak merfu olması gerekir. Zira müştegal fiil ile müştegalu 'anh isim arasında yer alan edatın sonrasıl كذا إذا الفِعْلُ تنا ما لْم beytinde ibtidaiyye olması gereken sadaret hakkı bulunan istifham edatları gibi kelimelerin isim ve fiil arasına girdiğinde iştigal konusu ile ilgisi varmış gibi ifadelerle anlatılması eleştirilmiştir. (İbn Hişâm, Evdahu'l-mesâlik, II, 161; İbn Kayyım, İrşâdu's-sâlik, I, 332) Bu muğlaklığa, beyitteki L'ların fesahatta ta'kîde sebep olduğu eleştirileri eşlik etmektedir. (el-Mekkûdî, Şerhu'lMekkûdî, II, 293)

\subsection{Farklı 1stılah kullanılması}

İbn Mâlik’in alışılmışın dışında kullandığı bazı ıstılahlar da eleştirilmiştir. Örneğin nahiv ıstılahında يُء olarak bilinen "ya" için o, ياء النتفل ifadesini kullanmıştır. (el-Mekkûdî, Şerhu’l-Mekkûdî, I, 125; İbn Tolun, Şerhu İbn Tolun, I, 111)

Ayrıca İbn Mâlik’in mazi fiile bitişen, تاء الضمير veya ناء الفاعل diye bilinen "tâ" için نَا فَعَلْتَ şeklinde kullandığı ifade, şârihlerin çoğu tarafından nefs-i mütekellimi kapsamadığı için uygun bir ifade olarak görülmemiş, (İbn Hişâm, Evdahu'l-mesâlik, I, 22; İbn Kayyım, İrşâdu's-sâlik, I, 83; İbn Akîl, Şerhu İbn Akîl, I, 22; el-Mekkûdî, Şerhu'l-Mekkûdî, I, 83) keza نائب الفاعل ifadesinin nev-i şahsına münhasır bir

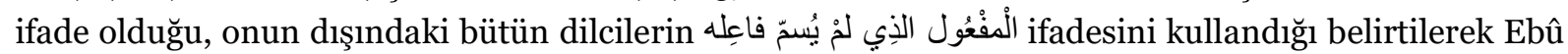


Hayyân tarafindan eleştirilmiştir. Ebû Hayyân, İrtişâfu'd-darab, III, 1325; İbn Tolun, Şerhu İbn Tolun, I, 327)

\subsection{Farklı illet sunulması}

Nunu'l-vikâyenin isimlendirilme illeti ile ilgili olarak dil bilimcilerin çoğunun görüşü fiilin sonunu kesradan koruduğu şeklindedir. Ancak İbn Mâlik buradaki illetin fiilin anlam karışıklığından korunması olduğu görüşündedir. Örneğin أكرمني fiilinde "nun" olmasa fiil, "muhataba ya"sı ile karışacaktır. (elMurâdî, Tevdîhu'l-mekâsıd, I, 377; (es-Suyûtî, el-Behcetu’l-merdıyye, s. 75)

\section{3. İçeriğe yönelik eleştiriler}

\subsection{Gereksiz detaylara girilmesi}

İbn Mâlik’i pek çok yerde eksik bıraktığı bir detay bilgiden dolayı tenkit eden şârihler, bazen de onun verdiği bir bilgiyi gereksiz ve detay bilgi görüp eleştirmişlerdir.

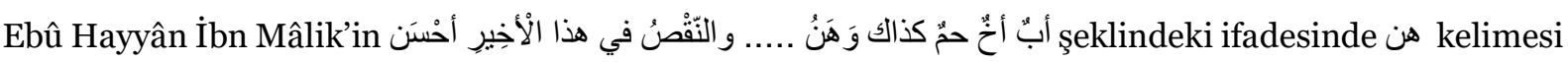
ile ilgili bir lehçe hakkında muhtemelen sanatsal yönü ağır bastığı için verdiği detay bilgiyi, hem nahvin konusuna girmediği hem de manzum ve muhtasar bir eser olan Elfiyye'ye yakışmadığı gerekçesiyle eleştirmiştir. (Ebû Hayyân, Menhecu's-sâlik, I/9) eş-Şâtıbî’nin, Ebû Hayyân'ın aksine İbn Mâlik'i ه kelimesi ile ilgili üçüncü bir kullanımı eksik bıraktığından dolayı eleştirmesi ise bu konuda ne kadar subjektif olunabileceğini göstermek noktasında dikkati muciptir. (eş-Şâtıbî, el-Mekâsıdu'ş-şâfiyye, I, 152

\subsection{Yanlış anlaşılmaya müsait beyitler}

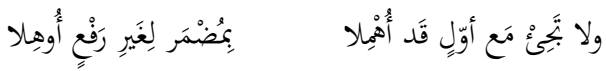

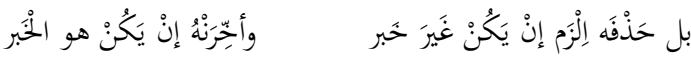

İbn Mâlik, tenazu' konusunu anlattığı bu iki beyitte Basra ekolüne göre ikinci amile amel verildiğinde birinci amile sadece merfu zamir getirileceğini, mansub zamirin haber olduğu durumda ise te'hir edilmesi, değilse hazfedilmesi gerektiğini söylemektedir. Örneğin ضَرَبتُ زَيدًا وَضَرَبَني "Zeyd'i dövdüm o da beni dövdü." cümlesinde birinci amil ضربتَ şeklinde kullanılmamıştır. Çünkü mansup zamir zaten "O beni (ayakta) zannetti, ben de Zeyd’i ayakta zannettim.” cümlesinde ise haber konumunda olduğu için cümle sonuna getirilmiştir. Ancak bu beyitler yanlış anlaşılmaya müsait olduğundan eleştirilmiştir. İbnu'n-Nâzım, el-Murâdî, İbnu'l-Verdî ve el-Eşmûnî̀ye göre İbn Mâlik’in ikinci beytinden anlaşllan ظنّ ve diğer kalp fiillerinin ikinci mefulleri haber olduğundan tehir edilip birinci mefulleri hazfedilmesi gerekir. Hâlbuki bu fiilerin birinci mansup zamirleri ile ilgili bir ifade yer almamaktadır. Oysa bu fiillerin birinci mefulleri ile ikinci mefulleri arasında hiçbir fark yoktur. Zira ikinci meful 'umde olup hazfedilemediği gibi birinci meful de 'umdedir ve hazfedilemez. Dolayısıyla

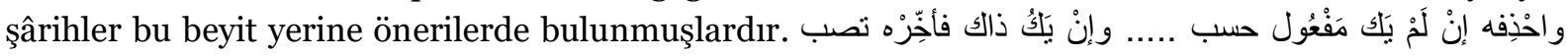
beyti de onlardan birisi de şudur: (İbnu'n-Nâzım, Şerhu İbnu'n-Nâzım, 188; el-Murâdî, Tevdîhu'lmekâsıd, II, 642; İbnu'l-Verdî, Tahrîru'l-hasâsa, 152)

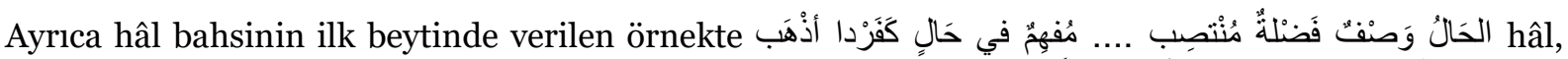

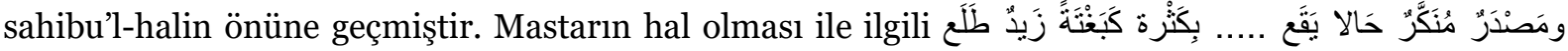


beyitteki بَ بَغْنَةَ زَيدُ طَلَع örneğinde de aynı şekilde sahibu'l-hal, hâl'den sonra gelmiştir. Zarurat-ı vezinden kaynaklı bir durum olsa da hükmü örnek üzerinden veren İbn Mâlik gibi biri açısından bakıldığında bu örnekler, hâlin sahibu'l-haldan önce gelmesinin olağan bir durum olduğu yanılgısına sebebiyet vereceği için şârihler tarafından eleştirilmiştir. (İbn Tolun, Şerhu İbn Tolun, I, 406.)

\subsection{Nazımda gramer kurallarını ihlali}

el-Mekûdî, Elfiyye'de aşağıdaki beyitlerin dil kuralları açısından problemli olduğuna belirtmiştir.

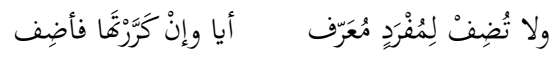

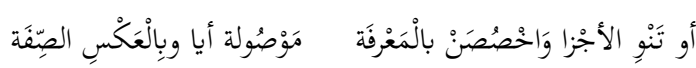

Zira bu beyitte şart edatt, كررنها şäl cümlesi, فأضف cevap cümlesidir. أو تنوي cümlesi ise كررتها üzerine atfedildiğinden o da şart cümlesidir. Hâlbuki cevap cümlesinin şart cümlesinden önce geldiği vaki değildir. (el-Mekkûdî, Şerhu’l-Mekkûdî, I, 435)

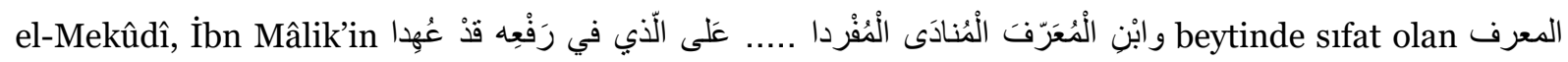
kelimesinin mevsufu olan المنادى kelimesinden önce gelmesini de eleştirmiştir. (el-Mekkûdî, Şerhu'lMekkûdî, II, 591) el-Miknâsî bunun şابن المنادى المفرد المعرفا ..... على الذي في رفعه قد عرفا edilmesi durumunda daha anlaşılır olacağını ifade etmiştir. (el-Miknâsî, Şerhu'l-Miknâsî, II, 212)

\subsection{Rivayetleri aktarırken oluşan hatalar}

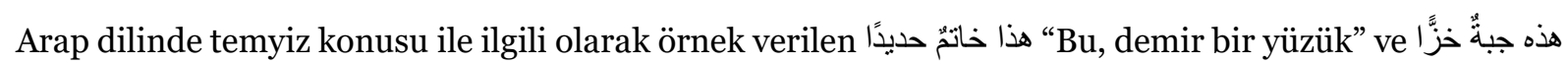
"Bu, ipek bir cübbe” örneklerindeki mansup kelimelerin temyiz mi hal mi oldukları tartışılagelmiştir.

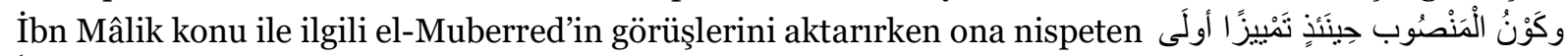
"Bu durumda mansup kelimenin temyiz olması hâl olmasından daha uygundur" ifadesini kullanmıştır. el-Ezherî’nin aktardıklarına göre burada el-Muberred'in görüşleriyle ilgili olarak "daha evladır" denilebilmesi için onun iki ayrı görüşünün olması gerekir. Hâlbuki el-Muberred konuyu açıklarken buradaki "demir" ve "ipek"in "yüzük" ve "cübbe”ye ait ayrılmaz bir vasıf olduğu için "hal olamayacağını” açıkça ifade etmektedir. (el-Muberred, III, 272; İbn Mâlik, Şerhu’t-teshîl, II, 382; elEzherî, Muvassılu'n-nebîl, II, 713, 714)

Bu konuya örnek olabilecek ikinci mesele ise terkip ifade eden yapıların "terhîm"inde söz konusudur. Arapçada تأبط شُرًا gibi fiil cümlesinden oluşan isimler vardır. Bu isimler münâdâ olduklarında terhîm

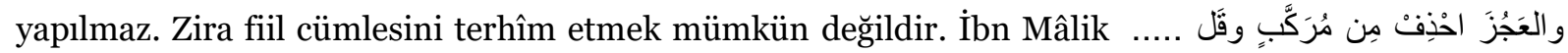
beytinde Arap dil bilimcilerin bu gibi isimlerde terhîm yapılabileceği görüşünün Sîbeveyhîyye dayandığını ifade etmiştir. Ona göre Sîbeveyhî terhîm babında böyle bir görüş serdetmemiştir. Fakat el-Kitab’nının başka bir yerinde Arapların تأبط شرًا başına kullandıklarını” söylemektedir. (Sîbeveyhî, el-Kitâb, II, 269; III, 377; İbn Mâlik, Şerhu't-teshîl, III, 422) Dolayısıyla bu terhîm yapılabileceğini gösterir. (es-Sabban, Hâşiyetu’s-Sabban, 1997, III, 266)

Sîbeveyhî’nin “Araplar tek başına kullanıyor” ifadesinin "terhîm yapıyorlar” demek midir? İbn Mâlik bu ifadeden bu sonucu nasıl çıkarmıştır? Şârihlerin üzerinde durduğu bu konuda Sîbeveyhî’nin terhimi caiz görmüş olmadığı ifade edilmiştir. Başka bir bağlamda istidrâk ifade eden bir cümleyi konu anlatılırken zikretmemiş olması, hatta özellikle konuyla ilgili babda bunu kabul etmemesi terhîmin yapılamayacağını açıkça göstermektedir. Her ne kadar eş-Şâtıbî gibi Sîbeveyhînnin görüşünü 
yorumlayarak İbn Mâlik’i haklı bulan müellifler olsa da (eş-Şâtıbî, el-Makasıdu'ş-şafiye, V, 439, 440) Ebû Hayyân ve Hâlid el-Ezherî gibi bazı şârihleri يا تأبط şeklinde terkip ifade etmeyen bir kelime olarak münâdâ olabileceğini ifade etmişlerdir. (el-Ezherî, Muvassilu'n-nebîl, III, 1224; Ebû Hayyân, İrtişafu'ddarab, V, 230) Bu durumda terhîm يا تأب şeklinde yapılabilecektir.

\section{5. İhtimal içeren veya net olmayan istişhadlar}

İbn Mâlik'in bazı konularda kullandığı mahalli şâhidler tartışmalıdır. Hâlbuki müelliften bir konunun açıklamasını yaparken yoruma açık olmayan, ihtimal içermeyen ve net olan deliller getirmesi beklenir. Örneğin "ب" harfi cerinin hal ifadelerinde kullanılabileceğini delillendirirken zikrettiği, (İbn Mâlik, Şerhu’t-Teshîl, II, 322)

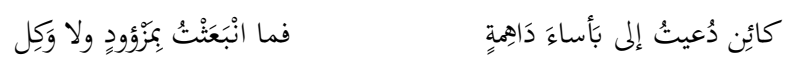

"Nice belalı zorluklara davet edildim, (Ben oralara) ne korkmuş olarak ne de aciz olarak gönderildim" beyti, üzerine hüküm bina edeceği kabilden bir şahid değildir. el-Murâdî, İbn Akîl, Ebû Hayyân ve Hâlid el-Ezherî gibi bazı şârihler İbn Mâlik’i bu konuyla ilgili açıçca eleştirmişlerdir. (el-Murâdî, el-Cene'ddânî, 1992, s. 56; İbn Akîl, II, 7, 8; Ebû Hayyân, et-Tezyil vet-tekmil, 1997, IX, 8; el-Ezherî, Muvassllu'nnebîl, II, 659) Zira burada فما انبعثت مزؤودًا ولا وكلاً انبعثُ ملتبسًا

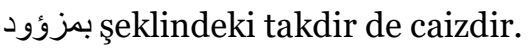

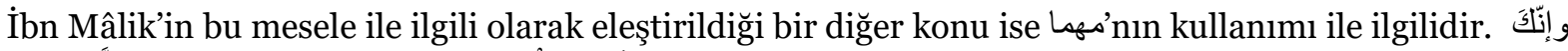

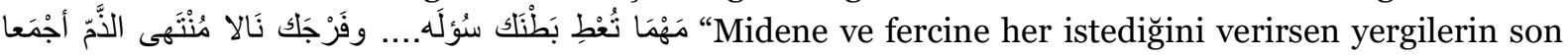
haddine ulaşırsın.” (İbn Mâlik, Şerhu’t-Teshîl, IV, 69)

İbn Akîl ve Hâlid el-Ezherîyye göre mastariye anlamı da imkân dâhilinde olan Hâtim et-Tâîye âit bu beyitteki مهo'nın zaman ifade eden şart edatına delil olarak kullanılması caiz değildir. (İbnu'n-Nâzım, Şerhu İbnu'n-Nâzım, IV, 69, İbn Akîl, Şerhu İbn Akîl, III,142; el-Ezherî, Muvassılu’n-nebîl, IV, 1554) Oğlu İbnu'n-Nâzım'ın da dâhil olduğu bu konuda İbn Mâlik'e yöneltilen eleştirinin odak noktası ise kat'î olmayan delille istidlal etmemesi gerektiği şeklindedir.

\subsection{Açıklayıcı olmayan örnekler}

İbn Mâlik farklı düşündüğü bir konuda görüşünü ispatlamak için getirdiği örneklerin konuyu açıklamaya yetmediği veya görüşüne delil olabilecek nitelikte olmadığı eleştirisini de almıştır.

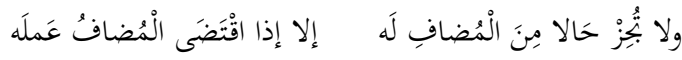

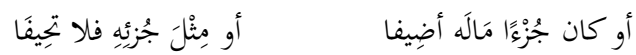

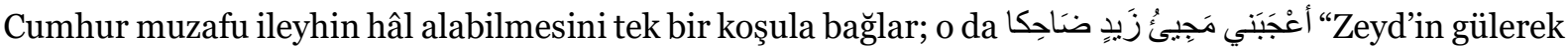
gelmesi hoşuma gitti.” örneğinde olduğu gibi muzafın, muzafu ileyhte amel etmiş olmasıdır. Ancak İbn

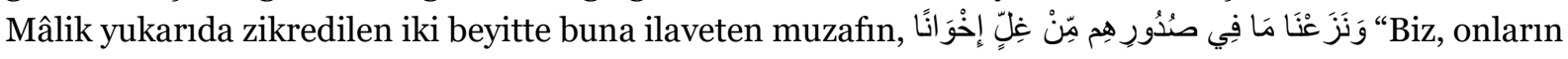
kalplerindeki kini söküp attık. Artık kardeşler olarak (onlar sedirler üzerinde, karşlılklı otururlar. el-

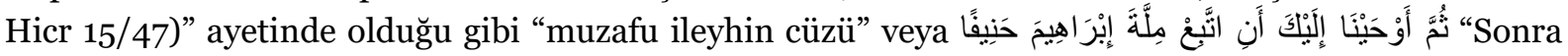
sana, 'Tevhid önderi olan ve putperestler arasında yer almamış bulunan İbrâhim'in dinine tabi ol' diye vahyettik. (en-Nahl, 16/123)" ayetinde olduğu gibi "muzafun ileyhin cüzü gibi” olması koşullarında da muzafu ileyhin hal alabileceğini söylemiştir. (İbn Mâlik, Şerhu’t-teshîl, II, 342) 
Ebû Hayyân ve İbn Câbir, İbn Mâlik'in bu hususta Cumhura muhalefet ettiğini ve onun iddiasını temellendirdiği örneklerin kendisi için delil olamayacağını öne sürmüşler. Zira إِخوَ kelimesi memduh

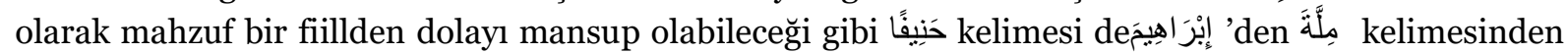
hâl'dir. (el-Murâdî, Tevdîhu'l-mekâsıd, II, 707; İbn Câbir, Şerhu İbn Câbir, II, 312)

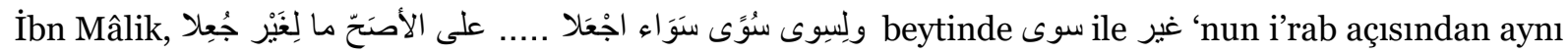

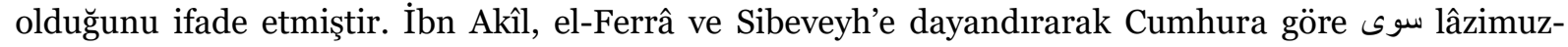
zarfiyet bir kelime olduğundan dolayı nasbın dışında ref' veya cer i’rabı alamaz, demektedir. O, İbn

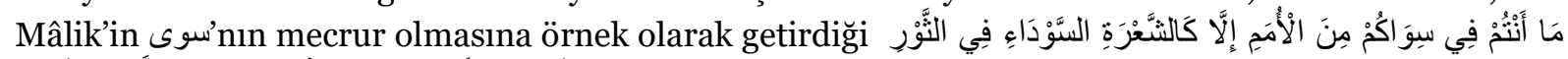
Siz, sizin dışındakiler içerisinde sadece siyah bir öküzün cildi üzerindeki beyaz bir tüy veya kırmızı bir öküzün cildi üzerindeki kara bir tüy kadarsınız” (Muslim, Sahih, I, 201) hadisinin veya merfu olmasına örnek gösterdiği beyitlerin görüşünü desteklemek için yeterli olmayan tevile muhtaç konular olduğunu ifade ederek bu hususta Cumhura muhalefet ettiğini söylemiştir. (İbn Akîl, Şerhu İbn Akîl, II, 230)

\subsection{Sarfa dair ayrıntılarda oluşan boşluklar}

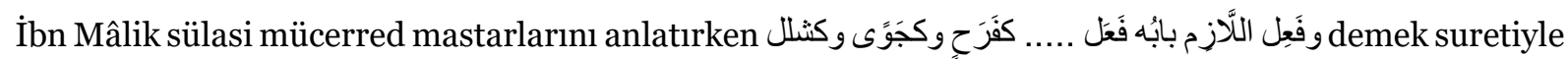
dördüncü babdan olan lazım fiillerin mastarları çoğunlukla فعِ vezninde geldiğini belirtir. Ancak bu bilgiyi yeterli görmeyen el-Murâdî, İbn Mâlik'in burada renk ifade etmeyenler şeklinde bir kayda yer vermesi gerektiğini, zira bu tür fiillerin mastarlarının çoğunlukla فُ vezninde geldiğini söylemiştir. (elMurâdî, Tevdîhu'l-Mekâsıd, III, 862)

el-Murâdî, İbn Mâlik’in tasğ̂̂r bahsindeki وصَغَّروا شُذُُوذاً الذي التي ..... وذا مع الفُروع مِنْها تاونى beytinde mevsul isimlerin tasğîrinin nasıl yapılacağını belirtmediği ve fer'i mevsul isimlerin hepsinde tasğîrin olabileceğini vehmettirdiği için eleştirmiştir. Nitekim mevsul isimlerin tasğgiri diğer isimlerden farklıdır ve fer’i mevsul isimlerden تَ tas̆̆̂îr edilmemektedir. (el-Murâdî, Tevdîhu'l-mekâsıd, V, 1442; İbn Câbir, Şerhu İbn Câbir, IV, 268)

\section{Sonuç}

İbn Mâlik'in Teshîlu'l-Fevâid ve Tekmîlu'l-Mekâsıd adlı eseri Arap gramerinin en temel eserlerindendir. Dünya dillerinde başka bir dilde görülemeyecek olan dil bilgisinin nazım şeklinde anlatımının şaheseri olan Elfiyye'si üzerine yapılan eleştiriler, Arap dil felsefesinin ne boyutlara ulaştı̆̆ını göstermesi açısından büyük önemi haizdir.

Bu çalışmada eserin şârihlerinin eleştirileri üç ana başlıkta toplanmış ve her başlıkta örnekler verilmiştir. Örnekler seçilirken tartışmaya mahal olmayan genelde şârihlerin yaptıkları ortak eleştiriler seçilmeye çalışılmıştır. Bu eleştiriler içerisinde en mühim olanı İbn Mâlik'in görüşlerindeki tutarsızlıklardır. İcmâya nisbet ettiği görüşlerindeki problemlerle üslup ve içerik bakımından yapılan hatalar da eleştirilerden payını almıştır.

Oğlu İbnu’n-Nâzım’ın eleştiri kapısını açmasının yanı sıra babası ve öğretmenine karşı takındığı eleştiri ahlakında çağdaş eğitim için anekdotlar mevcuttur. Hatta bu durum, eleştiri oranı en yüksek olan elMurâdî̀yi ve İbnu'l-Verdî̀yi etkileyen bir faktör olmuştur.

Gramer konularının manzum anlatımı, şairi kolayca izah edilebilecek konuların zor anlaşılmasına sebep olacak ifadeler kullanmak zorunda bırakmış, vezin ve kafiye gereği farklı şekilde ifade edilen kelime ve 
cümleler eleştiri konusu olmuştur. Diğer taraftan eleştirilerinin geneline baktı̆̆ımızda özellikle çoğunluk tarafından yapılan eleştirilerin haklı olduğu görülmekle birlikte ancak bir şerh veya haşiyede yer alabilecek detay bir bilginin eksik olduğu noktasında yapılan eleştirilerde nâzıma haksızlık yapıldığını söylemek mümkündür.

Görüşleri arasındaki tutarsızlıkların altındaki neden, muhtemelen bağlı bulunduğu Endülüs dil okulunun sentez bir dil okulu olmasıdır. Zira İbn Mâlik eserlerinden birinde Basra dil okulunun görüşünü tercih ederken, diğer eserinde Kufe dil okulunun görüşünü tercih etmiştir. Mesnetsiz olmayan bu durum tutarsızlık eleştirisine maruz kalma sebeplerinden biri olmuştur.

Eleştiri üslubu açısından bakıldığında şârihlerin eleştirilerinde insaf dairesinin dışına çıkmadıkları söylenebilir. Zira bazı eleştirilerinden sonra özür dilenmesi bunu göstermektedir. Üslubu en ağır olan şârihin Ebû Hayyân, temas etmeyi gerekli gördüğü yerler dışında eleştiride bulunmayan es-Suyûtî̀nin ise en naif eleştirmen olduğu söylenebilir.

Bir şârihin eleştirdiği konuda başka bir şârihin İbn Mâlik’i eleştirilere karşı savunması, konuya nesnel yaklaşma çabalarını göstermesi açısından önemlidir. Şârihlerin doğru olmadığını düşündükleri hâlde bazı konularda müellifin kastını görmeye çalışmaları iyi niyetli bir eleştirmen modelidir. Eleştirilerde seçilen kelimelere gösterilen itina ise gözetilen âlim vasfının nezaketini ortaya koyması açısından takdire şayandir.

\section{Kaynakça}

Abbas Hasan (1973). en-Nahvu'l-Vâfi, Kahire, Dâru'l-Maârif,

İbn Cinni, Ebu'l-Feth Osman el-Mevsıli, el-Lem' fi'l-Arabiyye (thk. Fâiz Faris) Kuveyt, Daru'l-Kutubu'sSekâfiyye, tsz.

Ebû Hayyân, Esîruddîn Muhammed b.Yusuf el-Ceyyanî el-Endelûsî (1984). İrtişafu'd-Darab min Lisani'l-Arab, (thk. Mustafa Ahmed Nehhas), Kahire, Mektebetu'l-Hanc1.

Ebû Hayyân (1997). et-Tezyil vet-Tekmil fỉ Şerhi Kitâbi't-Teshîl, (thk. Hasan Hindâvî), Şam, Dâru'lKalem.

el-Ezherî, Hâlid b. Abdillah (1998). Muvassllu'n-Nebîl ilâ Nahvi't-Teshîl, thk. Süreyya Abdussemî İsmail, (Basılmamış doktora tezi)

İbn Akîl, Ebû Muhammed Bahauddîn Abdullah b. Abdurrahman (1980). el-Musâ’'d alâ Teshîli’l-Fevaid, (thk. Muhammed Kamil Berekât), Mekke, Câmiatu'l-Melik Abdulazîz.

İbn Akîl (1999). Şerhu İbn Akil alâ Elfiyyeti İbn Mâlik, thk. Muhammed Muhyiddin Abdulhamid, Kahire, Dâru't-turâs.

İbn Câbir, Muhammed b. Ahmed b. Ali b. Câbir (2000). Şerhu Elfiyyeti İbn Mâlik, thk. Abdulhamid Seyyid Muhammed Seyyid Muhammed, Kahire, el-Mektebetu'l-ezheriyye li't-turâs.

İbn Hişâm, Ebû Muhammed Cemaleddin Abdullah b. Yusuf en-Nahvî (1994). Evdahu'l-Mesâik ilâ Elfiyyeti İbn Mâlik, (thk. Muhammed Muhyiddin Abdulhamid), Beyrut, Dâru'l-Fikr.

İbn Kayyım, el-Cevziyye (2004). İrşâdu's-sâlik İlâ Elfiyyeti İbn Mâlik, thk. Mahmud Nassar, Beyrut, Daru'l-Kutubi'l-İlmiyye.

İbn Mâlik, Ebû Abdullah Cemaleddin Muhammed b. Abdullah et-Tâî (1967). Teshîlu'l-Fevâid ve Tekmîlu'l-Mekâsıd, (thk. Muhammed Kamil Berakât), Birleşik Arap Emirlikleri, Dâru'l-Kâtibi'lArabî.

İbn Mâlik (1990). Şerhu't-Teshîl, thk. Muhammed Bedevi Mahtun, Abdurrahman Seyyid, Cîze, Hicr. 
İbn Mâlik (1982). Şerhu'l-Kafiyeti'ş-Şafiye, thk. Abdulmun'im Ahmed Herîdî, Mekke, Câmiatu Ummi'lKurâ.

İbnu'n-Nâzım, Ebû Abdullah Bedreddin Muhammed b. Muhammed, Şerhu Elfiyyeti İbn Mâlik, (thk. Abdulhamid Seyyid Abdulhamid), Beyrut, Dâru'l-Cîl, tsz.

İbn Tolun, Ebû Abdillah Şemsuddin Muhammed b. Ali (2002). Şerhu İbn Tolun alâ Elfiyyeti İbn Mâlik, (thk. Abdurrahman Câsim), Beyrut, Daru'l-Kutubi'l-İlmiyye.

İbnu'l-Verdî, Zeynuddin Ömer b. Muzaffer (2008). Tahrîru'l-Hasâsafí Teysîri'l-Hulâsa, Beyrut, Daru'lKutubi'l-îlmiyye.

el-Mekkûdî, Ebû Zeyd Abdurrahman b. Ali b. Salih (1993). Şerhu'l-Mekkûdî ala Elfiyyeti İbn Malik, (thk. Fatıma Raşid Racihi) Kuveyt, Câmiatu'l-Kuveyt

el-Muberred, Ebu'l-Abbas Muhammed b. Yezid b. Abdulekber el-Ezdi, el-Muktedab, (thk. Muhammed Abdulhalik Azime), Kahire, yy.

el-Murâdî, Hasan b. Kâsım (1992). el-Cene'd-Dânî fì Hurûfi'l-Me'ânî, (thk. Fahreddin Kabâve, Muhammed Nedîm Fâzıl) Beyrut, Daru'l-Kutubi'l-İlmiyye.

el-Murâdî (2001). Tavzîhu'l-makasıd ve'l-mesâlik bi-şerhi Elfiyyeti İbn Mâlik, (şrh. thk. Abdurrahman Ali Süleyman) Kahire, Dâru'l-Fikri'l-Arabi.

es-Sabban, Ebu'l-İrfan Muhammed b. Ali (1997). Hâşsiyetu's-Sabban ala Şerhi'l-Eşmûnî ala Elfiyyeti İbn Mâlik, Beyrut, Daru'l-Kutubi'l-İlmiyye.

Sîbeveyhî Ebû Bişr Amr b. Osman b. Kanber el-Hârisî, el-Kitâb, thk. Abdusselam Muhammed Harun, Kahire, tsz.

es-Suyûtî Ebu'l-Fazl Celaleddin Abdurrahman b. Ebî Bekr, Hem'u'l-Hevami fi şerhi Cem'ïl-Cevami, (thk. Abdulhamid Hindâvî), Mısır, el-Mektebetu't-Tevfîkıyye, tsz.

es-Suyûtî (2000). el-Behcetu'l-Marziyye fi Şerhill-Elfiyye, (thk. Ahmet İbrahim Ali), Beyrut, Dâru'l-fikr. eş-Şâtıbî (2007). Ebû İshak İbrahim b. Musa b. Muhammed el-Girnati, el-Makâsıdu'ş-Şafiye fi Şerhi’lHulasati'l-Kafiye, Mekke, Camiatu Ummi'l-Kura.

ez-Zemahşerî (1993). Ebu'l-Kâsım Cârullah Mahmûd b. Ömer b. Muhammed el-Mufassal fí San'ati'lI’rab, Beyrut, Mektebetu'l-Hilal. 